Российский национальный исследовательский медицинский университет им. Н.И. Пирогова

Морозовская детская городская клиническая больница

Возможности применения гомеопатического препарата Афлубин в лечении острых респираторных вирусных заболеваний у детей

\author{
М.С. Савенкова, д.м.н., проф.
}

Адрес для переписки: Марина Сергеевна Савенкова, mpsavenkov@mai.ru

Для цитирования: Савенкова М.С. Возможности применения гомеопатического препарата Афлубин в лечении острых респираторных вирусных заболеваний у детей // Эффективная фармакотерапия. 2020. Т. 16. № 34. С. 10-14.

DOI 10.33978/2307-3586-2020-16-34-10-14

В статье представлены титературные данные о гомеопатическом препарате Аблубин для комплексного течения гриппа и острых респираторных вирусных инбекиий у детей, возможности его применения в эпидемическом периоде подъема респираторных заболеваний, а также в качестве пробилактического средства. Обобщены данные, касаюшиеся основных свойств препарата. Компоненты, входящие в его состав, влияют на уменьшение симптомов интоксикации и температуры, способствуют облегчению кашля и боли. Абблубин может применяться у детей начиная с первого года жизни.

Ключевые слова: Абблубин, дети, грипп и другие острые респираторные вирусные инфекиии, лечение, профилактика

K назначению гомеопатических препаратов врачи относятся по-разному: одни с одобрением, другие - с долей скепсиса и сомнения, недоверия. И это пнятно, ведь у каждого врача имеется свой собственный опыт (положительный или отрицательный) применения гомеопатических препаратов. Среди врачебного сообщества есть специалисты с более углубленными знаниями в области гомеопатии, и они с успехом применяют их на практике. Я отношусь к сторонникам официальной медицины и выбора оптимальных лекарственных препаратов - противовирусных, антибактериальных, иммуномодулирующих и т.д.

Как известно, документально вся медицина делится на три катего- рии: официальная, традиционная (гомеопатия, фитотерапия, гирудотерапия) и нетрадиционная. Однако в практической работе мне, как и большинству врачей, неоднократно приходилось назначать гомеопатические препараты.

Попытаемся вместе разобраться и ответить на вопросы: кому показаны гомеопатические средства? кто их должен назначать? какие препараты наиболее часто используются в педиатрии?

\section{Немного истории}

Гомеопатия связана с именем Христиана Фридриха Самуэля Ганемана (Samuel Friedrich Christian Hahnemann, 1755-1843), который получил классическое медицинское образование в Лейпцигском университете. Однако не следует забывать о методах, которые применялись в то время: антисептиков не было, лечили такими препаратами, как сулема, мышьяк, хинин, использовали прижигания. Понимая, что такие методы лечения мало эффективны, Ганеман предпринял попытку обратиться за опытом к иностранным медикам. В 1790 г. он перевел книгу британского химика-фармаколога Уильяма Каллена «Materia medica», с которой непосредственно был связан его дальнейший путь. Исходя из собственной врачебной практики, Ганеман сформулировал принцип «simila similibus curantur», что означает «подобное лечится подобным». Такое лечение он назвал гомеопатией - в переводе с греческого «подобный, страдающий». Ганеман также ввел термин «аллопатия» - в переводе с греческого «чужой, страдающий», то есть лечение препаратами, вызывающими симптомы, противоположные симптомам болезни. В ходе экспериментов он выяснил, что снижение дозы (разведенное вещество) эффективнее более высокой дозы и менее токсично.

Не случайно ведущее место в развитии гомеопатии принадлежит именно Германии - как продолжателю данного направления. 


\section{Что означают цифры около ингредиентов в описании содержимого препаратов}

В гомеопатии разведения могут быть десятичные (последовательное многократное растворение первоначального субстрата) 1:10 (D), сотенные - 1:100 (C), тысячные - 1:1000 (M), пятидесятитысячные -1:50000 (LM).

Цифра, стоящая после разведения, обозначает порядковый номер разведения (например, С10, C11, С12 - 10-е, 11-е, 12-е сотенное разведение).

\section{Из какого естественного сырья готовят гомеопатические препараты и в каких формах}

Гомеопатические препараты изготавливают из естественного природного сырья растительного, животного и минерального происхождения. В педиатрической практике применяют как однокомпонентные, так и сложные (комплексные) гомеопатические препараты. Они выпускаются в разных формах:

$\checkmark$ для парентерального введения ампульные растворы (подкожно, внутривенно, внутримышечно);

$\checkmark$ для перорального применения (в виде таблеток, гранул, капель, карамелей);

$\checkmark$ в виде других форм - ректальных свечей, мазей, аэрозолей.

\section{Каковы общие правила применения гомеопатических препаратов}

Гомеопатические средства в виде ампул для парентерального введения применяются 1-3 раза в неделю:

- ампулы 1,1 мл: детям до двух лет - 1/3 объема раствора ампулы, с двух лет - 1/2 объема;

- ампулы 2,2 мл: детям до двух лет - 1/6 объема раствора ампулы, с двух лет - 1/4 объема.

Гомеопатические препараты внутрь принимают за 20-30 минут до еды или через час после еды:

- в каплях: для детей грудного и младшего возраста - 1-3 капли;

- в таблетках: дети до трех лет 1/2 таблетки, с трех лет - одна таблетка, в гранулах - 1-3 гранулы.
При пероральном применении препараты в ампулах рекомендуется растворить в воде, разделив всю дозу на 3-5 приемов. Доза при пероральном приеме аналогична парентеральной.

Варианты использования различных форм данной группы препаратов у детей зависят от возраста, целей, клинического диагноза. Гомеопатические препараты хорошо сочетаются с другими видами терапии.

Гомеопатические препараты назначает лечащий врач.

Безопасность применения гомеопатических средств даже детьми раннего возраста общепризнанна. Противопоказанием к назначению препарата может быть только индивидуальная реакция на какойлибо его компонент.

На практике гомеопатические препараты чаще применяют в целях лечения и профилактики острых респираторных вирусных инфекций (ОРВИ): гриппа, парагриппа, аденовирусной, риновирусной, РС-вирусной, коронавирусной, бокавирусной инфекции и т.д. Статистика показывает, что в России гриппом каждый год болеют свыше 60-70 млн человек.

Причиной ОРВИ являются более 200 типов вирусов, что создает определенные объективные трудности в профилактике данной группы заболеваний. Экономические потери исчисляются 15 трлн руб. в год.

Основные клинические симптомы, развивающиеся при гриппе и ОРВИ, связаны с лихорадкой, болью, катаральными явлениями, кашлем, изменением иммунной реактивности организма. В основе данных проявлений лежит прежде всего воспалительная реакция.
К сожалению, не многие лекарственные препараты можно назначать в раннем детском возрасте, особенно детям первых лет жизни. В случае правильно подобранного гомеопатического препарата можно уменьшить степень выраженности воспалительной реакции, симптомов респираторного заболевания, а также избежать назначения препаратов других групп. При тяжелом течении заболевания назначают препараты противовирусного действия, при развитии бактериальных осложнений - антибактериальные. Следовательно, если через два-три дня от начала монотерапии гомеопатическим препаратом облегчения не наступает, необходимо повторно обратиться к врачу для замены препарата или добавления другого лекарственного средства.

Одним из гомеопатических препаратов, часто применяемых в педиатрической практике при острых респираторных инфекциях, является Афлубин.

\section{Афлубин}

Афлубин (Австрия) производится в виде капель во флаконах темного цвета по 20, 50 и 100 мл, а также в таблетках.

Согласно инструкции, Афлубин показан в комплексной терапии и профилактике (плановой и экстренной) гриппа и других острых респираторных заболеваний, а также при воспалительных и ревматических заболеваниях, сопровождающихся суставным болевым синдромом. В целом компоненты, входящие в состав Афлубина, влияют на уменьшение симптомов интоксикации и температуры, способствуют облегчению кашля и боли (табл. 1).

Таблица 1. Влияние компонентов, входящих в состав Афлубина, на катаральные проявления, интоксикацию, ревматические боли, качель

\begin{tabular}{|l|l|l|l|l|}
\hline Компонент & $\begin{array}{l}\text { Катаральные } \\
\text { проявления }\end{array}$ & Интоксикация & $\begin{array}{l}\text { Ревматические } \\
\text { боли }\end{array}$ & Кашель \\
\hline Горечавка (Gentiana D1) & + & + & + & \\
\hline Борец (Aconitum D6) & + & + & + & + \\
\hline Переступень белый (Bryonia D6) & + & + & & + \\
\hline Фосфат железа (ferrum phosphoricum D12) & + & + & + & + \\
\hline $\begin{array}{l}\text { Молочная кислота } \\
\text { (асіdum sarcolacticum D12) }\end{array}$ & + & + & & + \\
\hline
\end{tabular}


В состав Афлубина входят:

$\checkmark$ горечавка желтая; обладает жаропонижающими свойствами, уменьшает симптомы интоксикации при ОРВИ;

$\checkmark$ аконит аптечный; снижает высокую температуру, уменьшает болевые ощущения;

$\checkmark$ железа фосфат; при заболеваниях органов дыхания оказывает противовоспалительное действие;

$\checkmark$ молочная кислота; способствует облегчению сухого кашля;

$\checkmark$ этиловый спирт - вспомогательное вещество;

$\checkmark$ переступень белый (бриония двудомная); способствует сокращению мышечных и суставных болей при комплексной терапии совместно с другими препаратами.

Афлубин в нашей стране начали применять более 20 лет назад. Фармакологическая целесообразность проведения профилактики и лечения Афлубином в периоде пре- и эпидемического подъема заболеваемости гриппом и другими ОРВИ была проанализирована и обобщена на основании статистических расчетов, согласно международной программе наблюдения, которая включала данные о 1600 случаях заболевания [1].

На фоне применения Афлубина

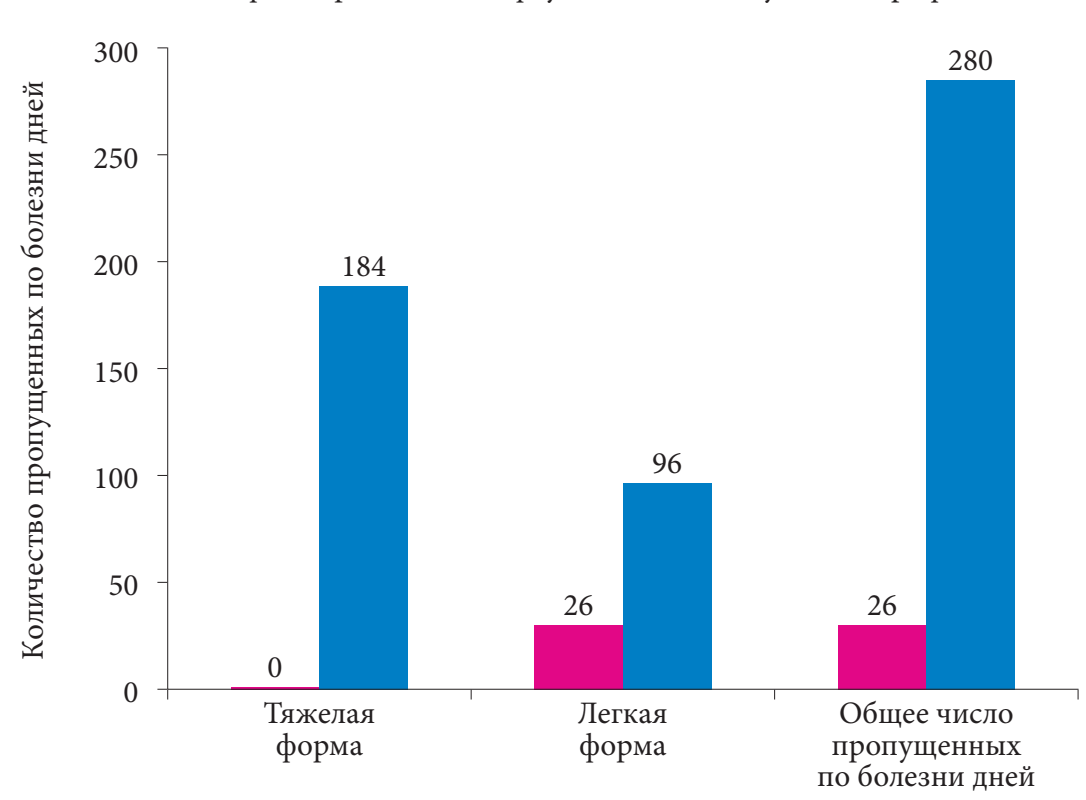

Эффективность Афлубина при гриппе и ОРВИ

Эффективность Афлубина, используемого в лечебных и профилактических целях при гриппе и других респираторных заболеваниях, обсуждалась в работе академика В.Ф. Учайкина и соавт. [2]. Авторы показали, что клиническая эффективность Афлубина выражается в уменьшении тяжести и продолжительности основных проявлений заболевания - лихорадки, симптомов интоксикации, катарального синдрома, а также более быстрой стабилизации кашля. Афлубин, применяемый в качестве профилактического средства при ОРВИ, достоверно снижает заболеваемость и предотвращает осложнения (рисунок) [2].

Афлубин применяют и для купирования субфебрильной температуры, когда применение жаропонижающих препаратов не показано.

Установлено, что Афлубин хорошо переносится пациентами, лишен побочных эффектов, совместим с другими препаратами (противовирусными и антибактериальными) $[2,3]$.

\section{Каким группам населения показана афлубинопрофилактика}

Проведение афлубинопрофилактики целесообразно [4]

В отсутствие профилактики
- среди членов организованного трудового коллектива;

- невакцинированных работников медицинских учреждений;

- персонала и детей в организованных детских коллективах независимо от прохождения вакцинации;

- лиц с высоким риском заболевания, которым вакцинация противопоказана в связи с иммунодефицитным состоянием; групп повышенного риска (дети, пожилые люди, больные диабетом, хроническими заболеваниями сердечно-сосудистой системы, органов дыхания, почек);

- контингента учреждений длительного ухода (дома престарелых, инвалидов);

- лиц с высоким риском заболевания в первые две недели после вакцинации против гриппа.

Афлубинопрофилактику можно проводить в разное время года, но лучше осенью, перед периодом эпидемического подъема заболеваемости. Плановая профилактика проводится в течение 20 дней во время эпидемического подъема. Экстренная профилактика в течение двух-трех дней рекомендуется в случае контакта с больным ОРВИ, гриппом, а также при воздействии таких факторов, как переохлаждение [4]. Как применять Афлубин при гриппе и острых респираторных заболеваниях, показано в табл. 2.

Профилактическая эффективность Афлубина у детей в возрасте до пяти лет составляет $84,2 \%$, в возрасте 6-12 лет - 96,5\%, у взрослых - 88,6\% [4].

Наряду с клинической эффективностью Афлубин характеризуется иммуномодулирующей активностью при ОРВИ, которая проявляется в увеличении синтеза секреторного иммуноглобулина А в слюне у детей всех возрастных групп и интерферона гамма у детей старше четырех лет [5]. Препарат Афлубин обладает интерферон-индуцирующей активностью, вызывая in vitro синтез интерферона в высоких титрах (160 Ед/мл), что сравнимо с действием препарата Амиксин, и превышает, по мнению авторов, 


\section{Афлубин ${ }^{\circledR}$ Для здоровья пять причин!}

\section{Aflubin}

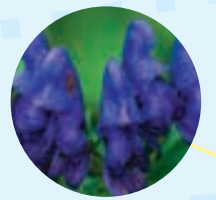

Борец

(Aconitum D6)

Молочная кислота

(Acidum sarcolacticum

D12)

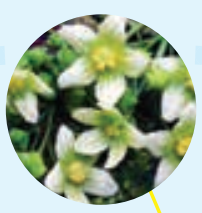

Переступень белый

(Bryonia D6)

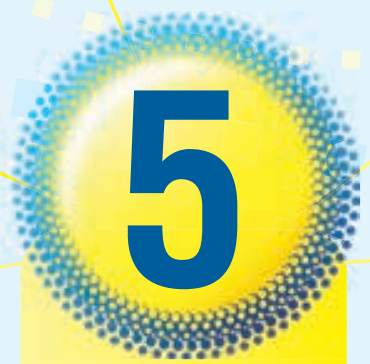

натуральных компонентов
Фосфат железа

(Ferrum phosphoricum D12)

$\checkmark$ Помогает облегчить симптомы гриппа и ОРВИ ${ }^{1}$

$\checkmark$ Без интенсивного жаропонижающего эффекта ${ }^{1}$

$\checkmark$ Показан для плановой и экстренной профилактики ${ }^{2}$

$\checkmark$ Натуральный состав ${ }^{4}$

$\checkmark$ Подходит малышам с первых дней жизни

$\checkmark$ Можно беременным ${ }^{4}$
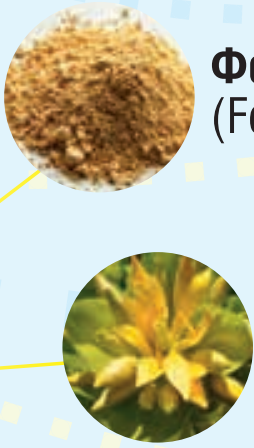

Горечавка желтая (Gentiana D1)

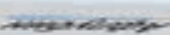

\section{Афлубин}

Aflubin

Для лечения

и профилактики

гриппа и простуды

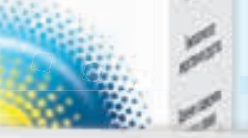

Афлуббин

Aflubini"

\section{Афлубин}

Aflubin'

rpunn

Простуда

Лечение

и профилактика

SAlvogen
'И.' Тишкина, Л.И. Ильенко, И.Н. Холодова. Новые возможности профилактики ОРЗ у детей раннего возраста. Практическая медицина. 1 (86) январь 2015

${ }^{2}$ Афлубин при гриппе и других ОРВИ: опыт применения для профилактики и лечения. // А.К. Токмалаев, Е.И. Склярова, Т.Ю. Никитская, И.А. Стеблюкова // Terra Medica. - 1998 №4. с.20-21.

${ }^{3}$ Клиническая эффективность Афлубина и его применение для неспецифической иммунопрофилактики гриппа и других ОРВИ // А.Н. Малышев, Е.П. Селькова, А.К. Токмалаев, И.А.

Стеблюкова // Эпидемиология и инфекционные болезни. - 1999. -№5. - с 44-45.

“Инструкция по медицинскому применению препарата Афлубин ${ }^{\circ}$ таблетки ЛС-000470. Необходима консультация специалиста.

${ }^{5}$ В.Ф. Учайкин и др. Афлубинотерапия и афлубинопрофилактика. Методические рекомендации. Детские инфекции 2007, №3, стр. 57-63

www.aflubin.ru

\section{Alvogen Россия \\ A ZENTIVA COMPANY}

000 «Алвоген Фарма», 123112, Москва,

Пресненская наб. д. 12, этаж 45, оф. 2

Тел.: +7 (499) 350-13-48

wWW.alvogen.ru

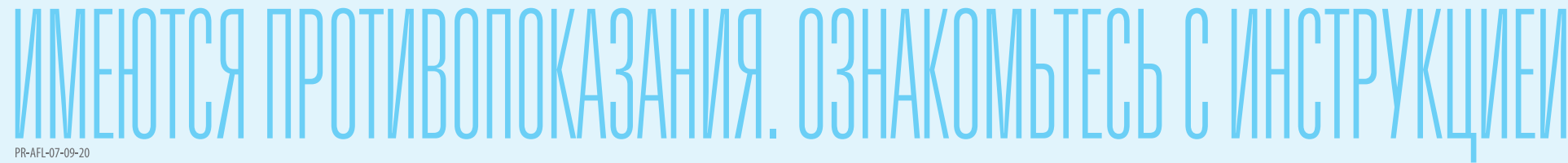


Таблица 2. Применение Афлубина при гриппе и острых респираторных заболеваниях (на разных этапах инфекционного процесса) согласно инструкции

\begin{tabular}{|c|c|c|c|}
\hline Возраст & Доза & Кратность приема & Способ введения \\
\hline \multicolumn{4}{|c|}{ Первый-второй день заболевания } \\
\hline Взрослые и подростки & 10 капель & \multirow{2}{*}{$\begin{array}{l}\text { От } 3 \text { до } 8 \text { раз в день } \\
\text { (не более) }\end{array}$} & \multirow{2}{*}{$\begin{array}{l}\text { Внутрь в чистом виде или развести в одной столовой } \\
\text { ложке воды за } 30 \text { минут до или через час после еды }\end{array}$} \\
\hline Дети от года до 12 лет & 5 капель & & \\
\hline \multicolumn{4}{|c|}{ Дальнейчее лечение клинических проявлений острых респираторных заболеваний или гриппа } \\
\hline Взрослые и подростки & 10 капель & \multirow{2}{*}{$\begin{array}{l}3 \text { раза в день, } \\
5-10 \text { дней }\end{array}$} & \multirow{2}{*}{$\begin{array}{l}\text { Внутрь в чистом виде или развести в одной столовой } \\
\text { ложке воды за } 30 \text { минут до или через час после еды, } \\
\text { подержав некоторое время во рту перед проглатыванием }\end{array}$} \\
\hline Дети от года до 12 лет & 5 капель & & \\
\hline \multicolumn{4}{|c|}{ Плановая пробилактика обострения заболевания в начале холодного времени года или перед эпидемией гриппа } \\
\hline Взрослые и подростки & 10 капель & \multirow{2}{*}{$\begin{array}{l}2 \text { раза в день, } \\
3 \text { недели }\end{array}$} & \multirow{2}{*}{$\begin{array}{l}\text { Внутрь в чистом виде или развести в одной столовой } \\
\text { ложке воды за } 30 \text { минут до или через час после еды, } \\
\text { подержав некоторое время во рту перед проглатыванием }\end{array}$} \\
\hline Дети от года до 12 лет & 5 капель & & \\
\hline \multicolumn{4}{|c|}{$\begin{array}{l}\text { Экстренная пробилактика (проводится сразу после контакта с заболевшим гриппом или острым респираторным } \\
\text { заболеванием или после сильного переохлаждения) }\end{array}$} \\
\hline Взрослые и подростки & 10 капель & \multirow{2}{*}{$\begin{array}{l}2 \text { раза в день, } \\
2 \text { дня }\end{array}$} & \multirow{2}{*}{$\begin{array}{l}\text { Внутрь в чистом виде или развести в одной столовой } \\
\text { ложке воды за } 30 \text { минут до или через час после еды, } \\
\text { подержав некоторое время во рту перед проглатыванием }\end{array}$} \\
\hline Дети от года до 12 лет & 5 капель & & \\
\hline
\end{tabular}

в 20-40 раз эффективность препаратов Ридостин и Циклоферон [6]. Таким образом, гомеопатический препарат Афлубин можно применять как в монорежиме при ОРВИ, так и в комбинации с другими лекарственными средствами. Афлубин может назначаться для лечения и профилактики респираторных заболеваний вирусной и смешан- ной этиологии. Его выгодно отличает возможность назначения детям начиная с первого года жизни, отсутствие побочных и аллергических реакций.

\section{Литература}

1. Лопатин П.В., Мальщеев Н.А., Стеблюкова И.А. Афлубин в лечении и профилактике гриппа и острых респираторных заболеваний // Здравоохранение Российской Федерации. 1999. № 6. С. 49-50.

2. Учайкин В.Ф., Харламова Ф.С., Кладова О.В., Замахина Е.В. Афлубинотерапия и афлубинопрофилактика. Методические рекомендации // Детские инфекции. 2007. Т. 6. № 3. С. 57-63.

3. Шамшева О.В., Учайкин В.Ф. Эффективность натурального препарата в лечении и профилактике гриппа и других острых респираторных заболеваний у детей // Детские инфекции. 2017. Т. 16. № 4. С. 63-66.

4. Мальшев Н.А., Селькова Е.П., Стеблюкова И.А., Смагулов К.З. Применение препарата Афлубин в комплексном лечении и неспецифической профилактике гриппа и острых респираторных болезней. Методические рекомендации (№ 47). М., 1999.

5. Крамарев С.А., Закордонеи Л.В., Евтушенко В.В., Толстоганова А.Н. Эффективность использования препарата «Афлубин» в комплексной терапии детей с ОРВИ // Современная педиатрия. 2014. № 6 (62). С. 56-61.

6. Гаращенко Т.И., Мезенцева М.И., Ильенко Л.И. Клинико-иммунологическое обоснование применения комплексного лекарственного препарата Афлубин в профилактике и лечении вирусных заболеваний респираторного тракта у детей // Детские инфекции. 2005. № 3. С. 49-53.

\section{Opportunity of Homeopathic Drug Aflubin Use in the Treatment of Acute Respiratory Viral Diseases in Children}

M.S. Savenkova, PhD, Prof.

N.I. Pirogov Russian National Research Medical University

Morozov Children's City Clinical Hospital

Contact person: Marina S. Savenkova, mpsavenkov@mai.ru

The article presents the literature data on the homeopathic drug Aflubin use for the complex treatment of influenza and acute respiratory viral infections in children, the opportunity of its use in the epidemic period of respiratory diseases, as well as in the form of a preventive tool. Summarized data concerning the main properties of the drug. The ingredients that make up the drug, affect the reduction of intoxication and temperature symptoms, contribute to the relief of coughing and pain. Aflubin can be used in children starting from the first year of life.

Key words: Aflubin, children, flu and other acute respiratory viral infections, treatment, prevention 